\title{
麻黄の副作用とエフェドリンアルカロイド除去麻黄エキス（EFE）の安全性
}

\author{
小田口 浩, ${ }^{a}$ 日向須美子, ${ }^{*}, a$ 関根麻理子, ${ }^{a}$ 中森俊輔, ${ }^{a, b}$ 竹元裕明, ${ }^{a, b,{ }^{\dagger}}$ 黄 雪丹, ${ }^{a, b}$

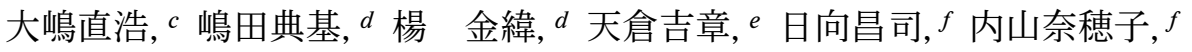 \\ 小林義典, ${ }^{a, b}$ 袴塚高志, $f$ 合田幸広, $f$ 花輪壽彦 $a$
}

\section{The Adverse Effects of Ephedra Herb and the Safety of Ephedrine Alkaloids-free Ephedra Herb Extract (EFE)}

\author{
Hiroshi Odaguchi, ${ }^{a}$ Sumiko Hyuga, ${ }^{*}, a$ Mariko Sekine, ${ }^{a}$ Shunsuke Nakamori, ${ }^{a, b}$ Hiroaki Takemoto,,${ }^{a, b, \dagger}$ \\ Xuedan Huang, ${ }^{a, b}$ Naohiro Oshima, ${ }^{c}$ Norimoto Shimada, ${ }^{d}$, Jinwei Yang, ${ }^{d}$ Yoshiaki Amakura, ${ }^{e}$ \\ Masashi Hyuga, ${ }^{f}$ Nahoko Uchiyama, ${ }^{f}$ Yoshinori Kobayashi, ${ }^{a, b}$ Takashi Hakamatsuka, ${ }^{f}$ \\ Yukihiro Goda, ${ }^{f}$ and Toshihiko Hanawa ${ }^{a}$ \\ ${ }^{a}$ Oriental Medicine Research Center, Kitasato University; 5-9-1 Shirokane, Minato-ku, Tokyo 108-8642, Japan: ${ }^{\text {SSchool of }}$ \\ Pharmacy, Kitasato University; 5-9-1 Shirokane, Minato-ku, Tokyo 108-8642, Japan: ' ${ }^{T}$ Tokyo University of Science Faculty of \\ Pharmaceutical Sciences; 2641 Yamazaki, Noda, Chiba 278-8510, Japan: ${ }^{d}$ Tokiwa Phytochemical Co., Ltd.; 158 Kinoko, \\ Sakura, Chiba 285-0801, Japan: ${ }^{\circ}$ Department of Pharmacognosy, College of Pharmaceutical Sciences, Matsuyama University; \\ 4-2 Bunkyo-cho, Matsuyama, Ehime 790-8578, Japan: and ${ }^{f}$ National Institute of Health Sciences; \\ 3-25-26 Tonomachi, Kawasaki-ku, Kawasaki 210-9501, Japan.
}

(Received May 14, 2019; Accepted July 9, 2019)

Ephedra Herb is defined in the 17th edition of the Japanese Pharmacopoeia (JP) as the terrestrial stem of Ephedra sinica StAPF., Ephedra intermedia SCHRENK et C.A. MEYER, or Ephedra equisetina BUnGE (Ephedraceae). The stems of Ephedra Herb contain greater than $0.7 \%$ ephedrine alkaloids (ephedrine and pseudoephedrine). Despite its high effectiveness, Ephedra Herb exert several adverse effects, including palpitation, excitation, insomnia, and dysuria. Both the primary and adverse effects of Ephedra Herb have been traditionally believed to be mediated by these ephedrine alkaloids. However, our study found that several pharmacological actions of Ephedra Herb were not associated with ephedrine alkaloids. We prepared an ephedrine alkaloid-free Ephedra Herb extract (EFE) by eliminating ephedrine alkaloids from Ephedra Herb extract (EHE) using ion-exchange column chromatography. EFE exerted analgesic, antiinfluenza, and anticancer activities in the same manner as EHE. Moreover, EFE did not induce adverse effects due to ephedrine alkaloids, such as excitation, insomnia, and arrhythmias, and showed no toxicity. Furthermore, we evaluated the safety of EFE in healthy volunteers. The number of adverse event cases was higher in the EHE-treated group than in the EFE-treated group, although the difference was not significant. Our evidence suggested that EFE was safer than EHE.

Key words — Ephedra Herb; ephedrine alkaloid; adverse effect; safety; ephedrine alkaloids-free Ephedra Herb extract

\section{1. はじめに}

麻黄は，第 17 改正日本薬局方において「本品は

Ephedra sinica STAPF, Ephedra intermedia SCHRENK

et C.A. MEYER 又は Ephedra equisetina BUNGE

(Ephedraceae) の地上茎である. 本品は定量すると
き，換算した生薬の乾燥物に対し，総アルカロイド [エフェドリン $\left(\mathrm{C}_{10} \mathrm{H}_{15} \mathrm{NO}: 165.23\right)$ 及びプソイド

エフェドリン $\left.\left(\mathrm{C}_{10} \mathrm{H}_{15} \mathrm{NO} ： 165.23\right)\right] 0.7 \%$ 以上を 含む」1) と規定されている。医療用漢方製剂 148 処 方中で麻黄が配合された処方は，16 処方（越婢加

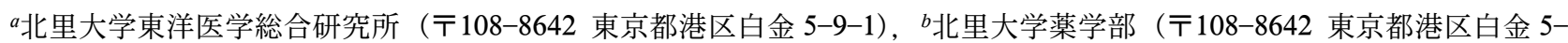

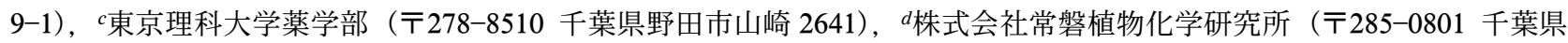
佐倉市木野子 158 番地), e松山大学薬学部（T790-8578 愛媛県松山市文京町 4-2), f国立医薬品食品衛生研究所（二2109501 川崎市川崎区殿町 3-25-26)

現所属: ‘東邦大学薬学部（广274-8510 千葉県船橋市三山 2-2-1）

*e-mail: hyuga-s@insti.kitasato-u.ac.jp 
术湯，葛根湯，葛根湯加川芦辛夷，葛根加术附湯， 桂枝麻黄各半湯，五虎湯，五積散料，小青竜湯，神 秘湯，続命湯，防風通聖散料，麻黄湯，麻黄附子細 辛湯，麻杏甘石湯，麻杏薏甘湯，薏苡仁湯）あり， 臨床で広く用いられている。.また，一般用医薬品に おいては，承認基準に従って麻黄を配合することが できる（一般用漢方製剂製造販売承認基準，薬生発 0328 第 1 号 平成 29 年 3 月 28 日発出; 平成 29 年 7 月 4 日 薬生発 0704 第 4 号 一部改正 鎮咳去痰薬の 製造販売承認基準)。他方，食薬区分において，麻 黄は「専ら医薬品」であるため, 食品として用いる ことはできない（平成 30 年 4 月 18 日薬生発第 0418 第 4 号, 厚生労働省医薬局長通知「医薬品の 範囲に関する基準の一部改正について」).

麻黄の主成分としては，エフェドリンが有名であ る。明治 18 年 (1885), 長井長義 (1848-1929) は, 麻黄から有効成分としてアルカロイドを抽出し，構 造決定した。このアルカロイドは，マオウ属 (Ephedra，エフェドラ属）から得られたことから， エフェドリンと命名された. ${ }^{2)} こ れ は ，$ 漢方で使用 する生薬から化学物質が抽出された最初の偉業であ り，近代における漢方の科学的研究の端緒となつ た．このような歴史的偉業として，エフェドリンは 麻黄から同定されたため, その後, 麻黄の他の有効 成分探索はあまりなされず，成書にも「他にフラボ ノイド類やタンニン, 多糖類などを含む」と記載さ れるに留まっている [伊田喜光，寺澤捷年 監修, 鳥居塚和生 編著「モノグラフ 生薬の薬効・薬理」 医歯薬出版株式会社（東京），2003 年，第 1 版]. また，生薬には多くの成分が含まれているが，漢方 医学では伝統的に生薬を最少単位と考え，その組み 合わせによる効果の相違に着目してきた背景と, 科 学技術の未熟さゆえに, 有効成分の単離・構造解析 という研究の方向性が取れなかったという現実も あった。実際，1980 年代に西岡は，麻黄のタンニ ンの構造解析を行い, 薬学雑誌にその構造式を発表 しているが，「麻黄のタンニンは通常の縮合型タン ニンではこれまで私共が手掛けた中で最も複雑な構 造で，4量体以上のものの単離は中断している」3) と 書かれている。

麻黄の薬効としては，発汗，解熱，鎮咳，抗炎 症，鎮痛作用などが知られており，これらの薬効は エフェドリンアルカロイドで説明できると考えられ
てきた. エフェドリン及びプソイドエフェドリンの 構造はアドレナリンに類似しており，アドレナリン 受容体を刺激し，気管支拡張や鼻粘膜充血の除去作 用を示すと考えられている．また，麻黄の抗炎症作 用はプソイドエフェドリンによるとの報告4)や，工 フェドリンアルカロイドがプロスタグランジン E2 の生合成阻害作用を有するとの報告(5)がある，原 田6) は，脱アルカロイド麻黄エキスを作製し，その 薬効を解析している．脱アルカロイド麻黄エキス は, 生薬の麻黄を $\mathrm{NH}_{4} \mathrm{OH}$ とエーテルで処理し, できるだけ脱アルカロイドをした麻黄を乾燥し，こ れを用いて水性エキスを作り，これにエーテル処理 で溶けだした中性成分を添加したものである．脱ア ルカロイド麻黄エキスでは，麻黄の治療効果と相関 する薬理作用が低下したことから，麻黄の作用はア ルカロイドでほとんど代表されると結論している.

\section{2. 麻黄及び麻黄配合漢方薬の副作用}

医薬品医療機器総合機構 (Pharmaceuticals and Medical Devices Agency；PMDA）の「副作用が疑 われる症例報告に関する情報」に，麻黄配合漢方薬 の副作用症例が報告されており，麻黄に含まれるエ フェドリンアルカロイドによる副作用と推察される 症例を Table 1 にまとめた．副作用としては，心機 能に対する有害事象や呼吸困難，及び，尿閉が多 い。 ヒトの心臓は主に $\beta 1$ アドレナリン受容体を発 現しており，エフェドリンアルカロイドの刺激に よって，心拍数増加や収縮力の増加を生じ，不整脈 や動悸を誘発すると考えられる．また，このような 心臓に対する影響により，患者は息苦しさや胸苦し さを覚え，呼吸困難を訴えたと推察された。尿閉 は，エフェドリンアルカロイドがアドレナリン $\beta 2$ 受容体を刺激して膀胱平滑心を弛緩させ，外尿道括 約筋を収縮させることで排尿抑制を引き起こしてい ると考えられる。また，麻黄が配合された一般用製 㓮の麻杏薏甘湯加防已の販売後調査 ${ }^{7)}$ で，薬剤との 関連性を否定できない有害事象として交感神経刺激 様症状（血圧上昇，めまい，ふらつき，不眠，動悸 等）が報告されている。 さらに，麻黄附子細辛湯の 市販後調查 ${ }^{8)}$ で，エフェドリンアルカロイドによる と考えられる副作用の発生頻度は，動悸，不整脈，

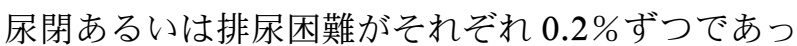
たと報告されている，実際，臨床において，麻黄配 合漢方薬は，非常に切れ味のよい優れた薬効を持つ 
Table 1. Information on Case Reports of Suspected Side Effects from the Pharmaceuticals and Medical Devices Agency (PMDA)

\begin{tabular}{cccc}
\hline \hline Suspected drug & Age & Sex & Side effects/Adverse events \\
\hline kakkonto & $70 \mathrm{~s}$ & female & cardiopulmonary arrest \\
kakkonto & unclear & male & ischuria, cystitis, dysuria \\
kakkonto & $60 \mathrm{~s}$ & female & dyspnea \\
kakkonto & $60 \mathrm{~s}$ & male & palpitation, dyspnea, heart failure \\
maobushisaishinto & $70 \mathrm{~s}$ & male & ischuria \\
maobushisaishinto & $60 \mathrm{~s}$ & male & ischuria \\
maobushisaishinto & $10 \mathrm{~s}$ & male & altered state of consciousness, hallucination \\
maobushisaishinto & $10 \mathrm{~s}$ & male & hypesthesia of mouth, second-degree atrioventricular block \\
bofutsushosan & $30 \mathrm{~s}$ & female & pulmonary arterial hypertension \\
bofutsushosan & $40 \mathrm{~s}$ & male & cerebral infarction \\
maoto & $50 \mathrm{~s}$ & female & dyspnea \\
shoseiryuto & $70 \mathrm{~s}$ & male & dyspnea \\
\hline
\end{tabular}

一方で，高齢者や虚弱者，高血圧傾向の者には不 眠，興奮，動悸，不整脈，血圧上昇，排尿障害など が出易く，使い難い面がある．このため，麻黄が配 合された漢方薬は，循環器系障害，高血圧症，及び 腎障害のある患者や，体力の衰えている者，高齢者 に対して使用上注意を要する.

米国では，麻黄をサプリメントとして使用してい たが，過剩摂取などの不適切な使用から死亡事故が 発生したことを受け，米国食品医薬品局（Food and Drug Administration; FDA）は，麻黄などのエ フェドリンアルカロイドを含むものについては，一 切の販売を禁止することを定め，消費者に対しても 注意喚起している (2004 年エフェドラ禁止令)。そ の根拠となったランドレポートでは，膨大な数の論 文とFDAに届けられた百数十件の死亡例を含む 1 万数千件の副作用報告を綿密に検証し，麻黄製剂 には動悸や悪心嘔吐などの軽度から中等度の副作用 があると結論付けている. 9,10)

エフェドリン及びプソイドエフェドリンは，世界 アンチ・ドーピング機構（World Anti-Doping Agency；WADA）が規定した禁止薬物であり，麻 黄の配合された感冒薬（麻黄湯，葛根湯，麻杏甘石 湯など）や，関節痛及び筋肉痛の治療薬である（麻 杏蔌甘湯，越婢加术湯及び薏茨仁湯など）をアス リートが服用すると，ドーピング検査で陽性になる 危険性が高い。 1984 年のロサンゼルス・オリン ピックでは，風邪を引いた日本男子バレーボール選 手が，トレーナーから渡された葛根湯を服用し， ドーピング検査でエフェドリンが検出された。これ
は，葛根湯に配合されていた麻黄が原因である。し たがって，競技会前のアスリートは，麻黄が配合さ れた漢方薬を服用する際には注意を要する.

さらに，エフェドリンやプソイドエフェドリンか ら覚せい剤を製造できるため，これらを $10 \%$ 以上 含有するものは覚せい剂原料として取り締まりの対 象となる（覚せい剂取締法）。中永, 五十嵐 ${ }^{11)}$ は, 麻黄が薬物中毒検出用キットのトライエージ®のア ンフェタミン類と交差反応を示したことを報告して いる.

3. エフェドリンアルカロイド除去麻黄エキス (ephedrine alkaloids-free Ephedra Herb extract; EFE)

これまで，麻黄の薬理作用と副作用は，主成分の エフェドリンアルカロイドに由来すると説明されて きたため，麻黄から副作用成分を除去することは無 益であると考えられていた。 しかし，われわれの研 究 ${ }^{12,13)}$ から, 麻黄の一部の薬理作用 (鎮痛作用, 抗 インフルエンザ作用，抗がん作用）はエフェドリン アルカロイドに依存しないことが明らかになり，麻 黄エキス（Ephedra Herb extract; EHE）からエフェ ドリンアルカロイドを除いても，いくつかの薬理作 用は残ることが示唆された。そこで，日本薬局方の 麻黄を熱水抽出して EHE を作製し，EHEに含ま れるエフェドリンアルカロイドを，陽イオン交換力 ラムを用いて除去して，エフェドリンアルカロイド 含量が検出限界以下 $(<0.05 \mathrm{ppm})$ のエフェドリ ンアルカロイド除去麻黄エキス (EFE) を製造した. EHE から製造される EFEの割合は，EHE 量の約 


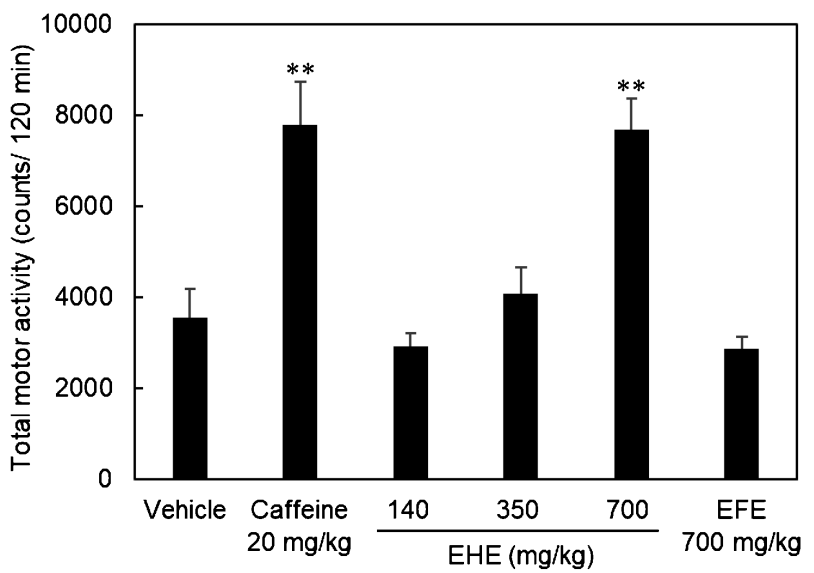

Fig. 1. Total Motor Activity of Mice in an Open-field Test Locomotor activity was measured for $120 \mathrm{~min}$ after oral administration of caffeine $(20 \mathrm{mg} / \mathrm{kg})$, EHE $(140,350,700 \mathrm{mg} / \mathrm{kg})$ or EFE $(700 \mathrm{mg} / \mathrm{kg})$. Data represent the means \pm S.E.M. $(n=8)$. Statistical significance was determined with Dunnett's test; ${ }^{* *} p<0.01 v s$. vehicle group. EHE, Ephedra Herb extract; EFE, ephedrine alkaloids-free Ephedra Herb extract. Reproduced in part with permission from Biol. Pharm. Bull. Vol. 41 No. 2 Pages 247-253. Copyright 2018 The Pharmaceutical Society of Japan.

84\%であった。また，EFEと EHE の含有成分を比 較検討した結果，EFE は 6-methoxykynurenic acid, 6-hydroxykynurenic acid 及び trans-cinnamic acid が EHE に比べて減少していた. ${ }^{14)}$ 6-Methoxykynurenic acid，及び，6-hydroxykynurenic acid は，構造中 に窒素を有するため，陽イオン交換樹脂に結合した ためではないかと考えられるが，trans-cinnamic acid は $\pi-\pi$ 相互作用による吸着ではないかと考え ている.

EFE の薬理作用 ${ }^{13)}$ については，鎮痛作用，抗个 ンフルエンザウイルス作用，抗がん作用が確認され た。ホルマリン試験によって，EFE は EHE と同様 に炎症性疼痛に対する鎮痛作用を有することが示唆

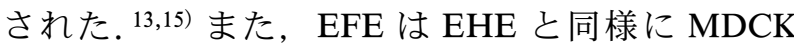
細胞へのインフルエンザウイルス感染を阻害するこ とが明らかになった。ささらに，EFE は EHE と同様 に，がんの増殖，浸潤，転移に関与する肝細胞増殖 因子受容体 c-Met を阻害することにより，抗がん 作用を示すこともわかった。一方，エフェドリンア ルカロイドに由来する気管支拡張作用や鼻閉に対す る治療効果は，EFEでは失われていると考えられ る.

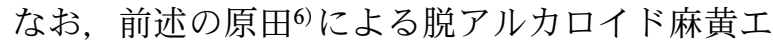
キスと EFE は，製造法が異なり，含有成分も異な ると考えられる，脱アルカロイド麻黄エキスは，残 存総アルカロイドを高濃度 $(0.33-0.5 \%)$ で含んで
A.

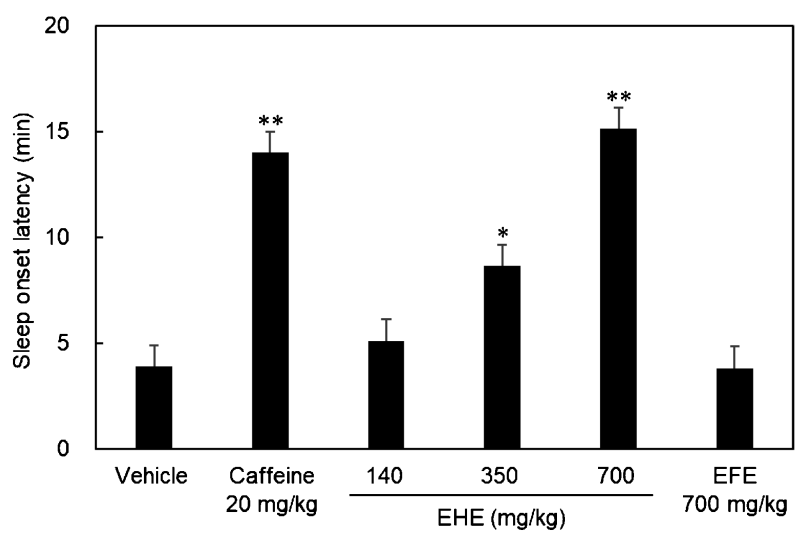

B.

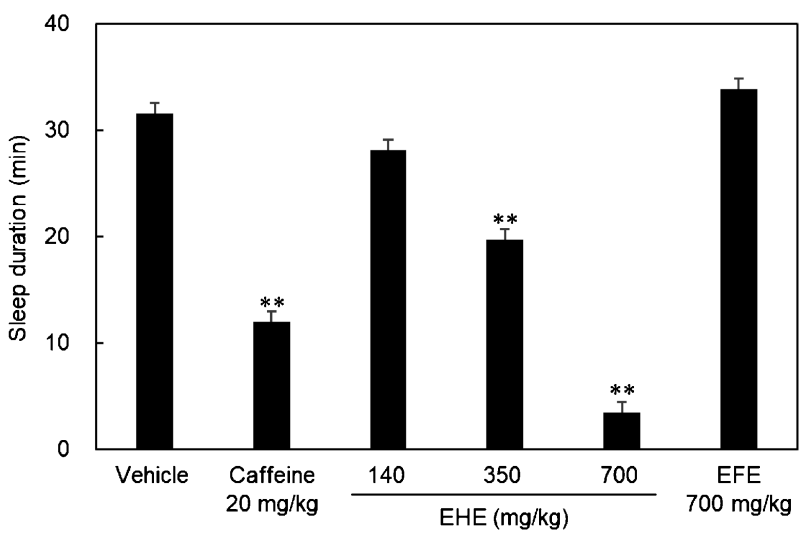

Fig. 2. Effects of Caffeine, EHE, and EFE on Pentobarbitalinduced Sleep Onset Latency and Sleep Duration in Mice

Caffeine $(20 \mathrm{mg} / \mathrm{kg})$, EHE $(140,350,700 \mathrm{mg} / \mathrm{kg})$, or EFE $(700 \mathrm{mg}$ $\mathrm{kg}$ ) was administered orally 30 min before intraperitoneal injection of pentobarbital. After intraperitoneal injection of pentobarbital, the sleep onset latency (A) and sleep duration (B) were recorded. Data represent the means \pm S.E.M. $(n=8)$. Statistical significance was determined with Dunnett's test; ${ }^{*} p<0.05,{ }^{* *} p<0.01 v s$. vehicle group. EHE, Ephedra Herb extract; EFE, ephedrine alkaloids-free Ephedra Herb extract. Reproduced in part with permission from Biol. Pharm. Bull. Vol. 41 No. 2 Pages 247-253. Copyright 2018 The Pharmaceutical Society of Japan.

おり，さらに， $\mathrm{NH}_{4} \mathrm{OH}$ 処理は，植物成分の構造に 化学的変化を起こす16,17)ことから, 元の麻黄エキス とは異なる artificial な成分を含有している可能性 がある．原田6)も論文中で，麻黄の $\mathrm{NH}_{4} \mathrm{OH}$ 処理に より若干の成分に変動が起こり，かならずしも元の 麻黄そのままの形態とは言えないと述べている．ま た，脱アルカロイド麻黄エキスは，麻黄の有する薬 理効果がすべて失われていたことから，麻黄の薬効 に影響を与える製造方法であったと推察される。

\section{4. 麻黄の副作用と EFE}

麻黄のエフェドリンアルカロイドに由来すると考 えられる副作用（興奮，不眠，及び，心機能に与え る影響) が，EFE で発現するのかどうかを検証す 

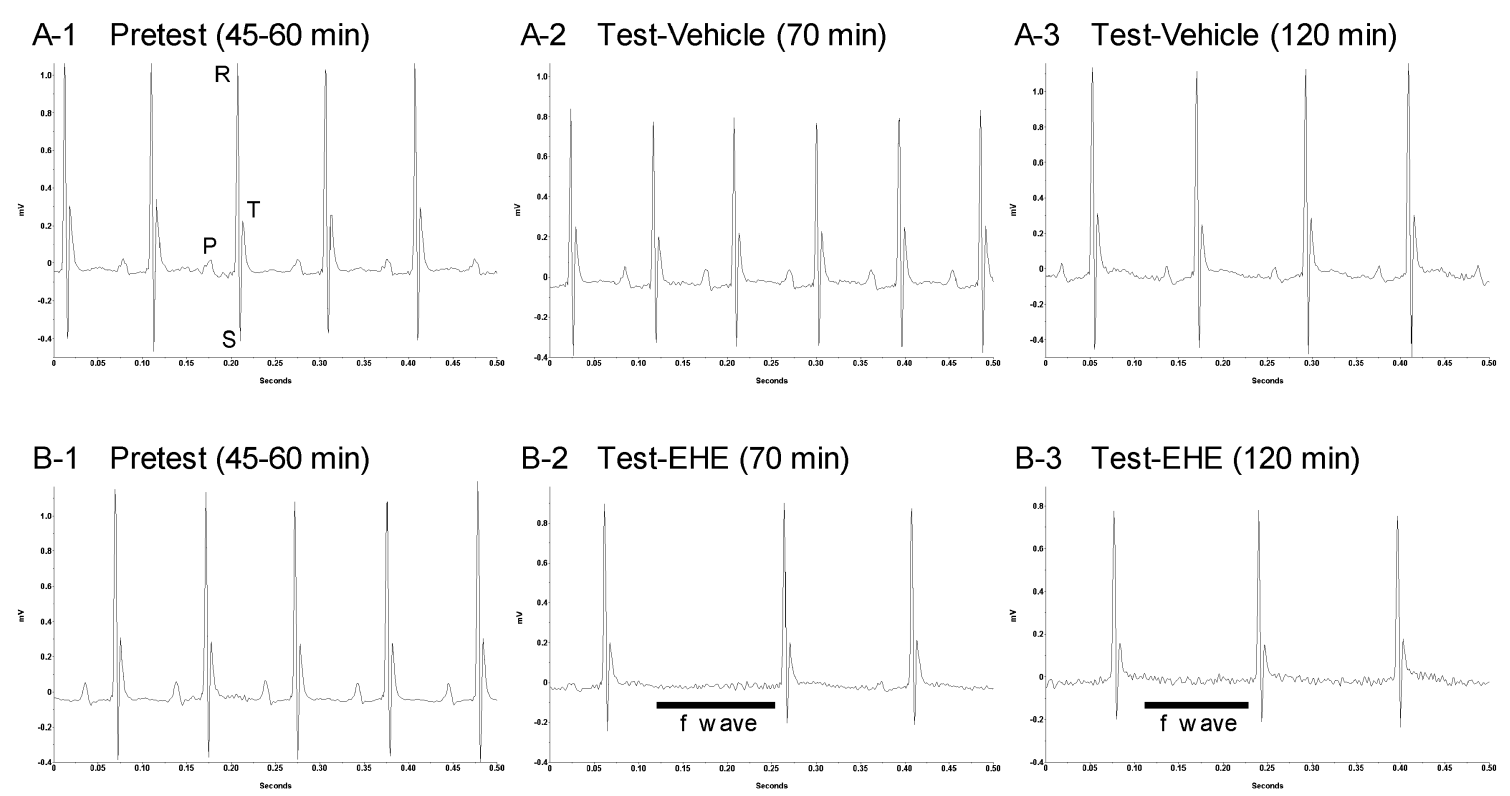

B-2 Test-EHE (70 min)

B-3 Test-EHE (120 min)
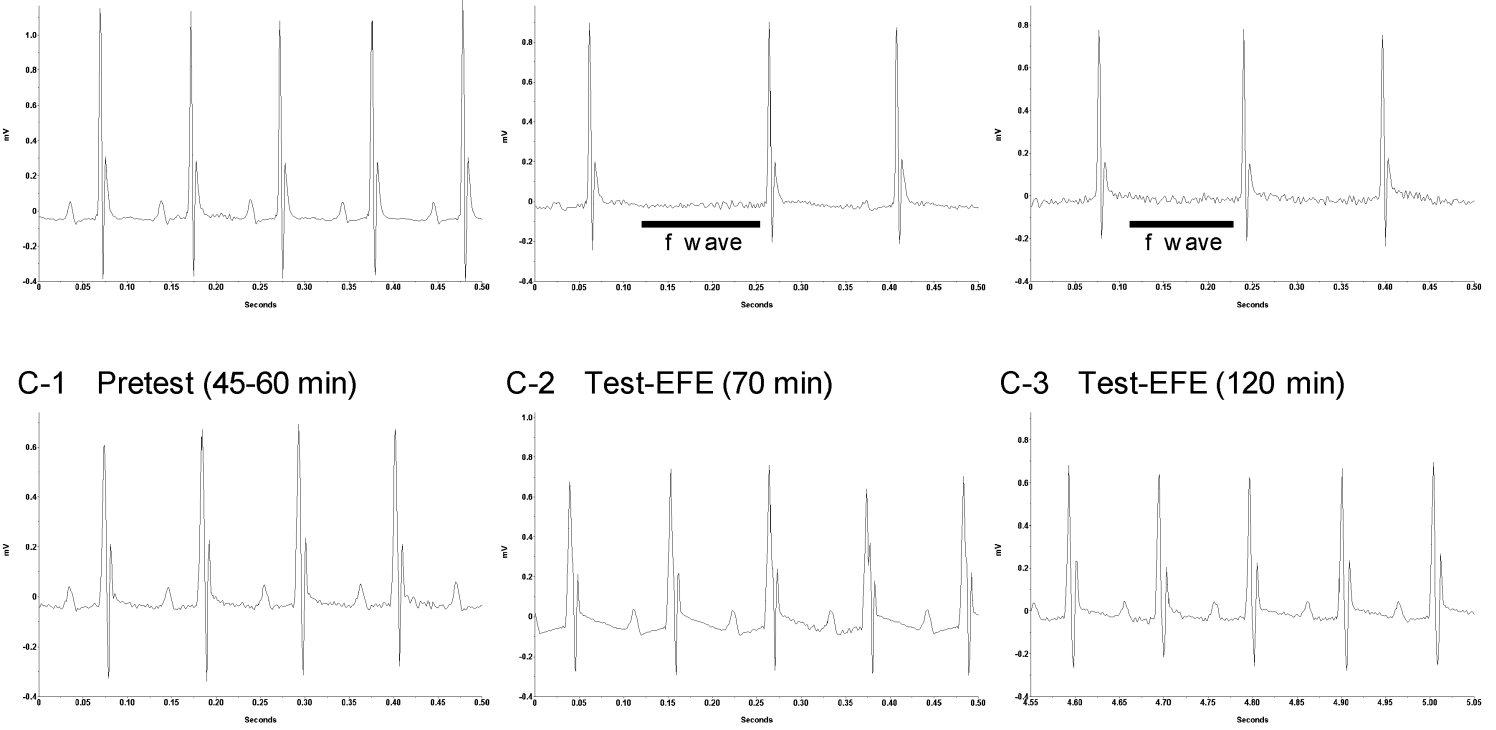

C-3 Test-EFE (120 min)

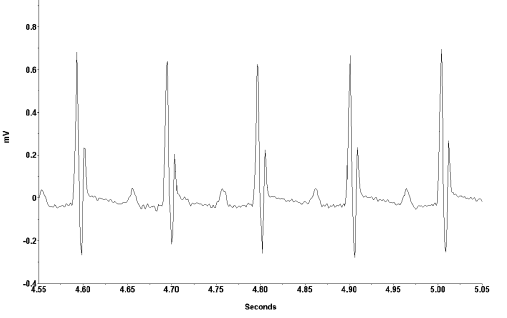

Fig. 3. Electrocardiogram Recordings for Mice Administered Vehicle, EHE, or EFE

Electrocardiograms were recorded in the pretest period (A-1, B-1, and C-1), and the test period from 10 and 60 min after administration of vehicle (A-2 and A-3, respectively), $700 \mathrm{mg} / \mathrm{kg}$ EHE (B-2 and B-3, respectively), and $700 \mathrm{mg} / \mathrm{kg}$ EFE (C-2 and C-3, respectively). Representative 0.5-s tracings are shown. EHE, Ephedra Herb extract; EFE, ephedrine alkaloids-free Ephedra Herb extract. Reproduced in part with permission from Biol. Pharm. Bull. Vol. 41 No. 2 Pages $247-$ 253. Copyright 2018 The Pharmaceutical Society of Japan.

るために，マウスを用いたin vivo 試験を行つた. ${ }^{18)}$

オープンフィールド試験において，EHE 経口投 与マウスの自発運動量は, EHEの用量依存的に増 加し, $700 \mathrm{mg} / \mathrm{kg}$ EHE 投与マウスは, $20 \mathrm{mg} / \mathrm{kg}$ 力 フェイン投与マウスと同程度まで自発運動量が増加 した。一方， $700 \mathrm{mg} / \mathrm{kg}$ EFE 投与マウスの自発運 動量は水投与マウスと有意差がなかった（Fig. 1).

これらの結果から, EHE はカフェインと同様の興 奮作用を示すのに対して， EFE はこのような副作 用がないことが明らかになつた。

ペントバルビタール誘発睡眠試験では， EFE 投 与マウスの睡眠誘導時間と睡眠時間は, 水投与マウ スと同等であった。一方，EHE 投与マウスの睡眠 誘導時間は，水投与マウスと比較して有意に延長 し，睡眠時間は有意に減少した。また， $700 \mathrm{mg} / \mathrm{kg}$ EHE の作用は $20 \mathrm{mg} / \mathrm{kg}$ のカフェインの作用より も強かった。これらの結果から, EHE は睡眠阻害
作用を誘発するのに対して，EFE は睡眠に影響を 与えないことが明らかになった（Fig. 2).

マウスの心拍変動解析では $700 \mathrm{mg} / \mathrm{kg}$ EHE 投与 マウスで催不整脈作用が観察され，心電図において $\mathrm{P}$ 波が減弱して $\mathrm{f}$ 波が出現し, 心房細動が起きてい ることが示唆された（Fig. 3)。一方， $700 \mathrm{mg} / \mathrm{kg}$ EFE 投与マウスでは，異常は観察されなかった.

以上の結果から, EHE はエフェドリンアルカロ イドに由来すると考えられる副作用（興奮, 不眠, 不整脈）を示したが，EFEではこれらの作用が認 められなかった。したがって, EFE は EHEに比べ て副作用が少なく, 安全性が高いことが示された。

\section{EHE と EFE の反復投与毒性試験}

EFEの安全性を検証するために，EHEを対照と して，マウスに対する反復投与毒性試験を行っ た. ${ }^{13)} 5$ 週令のマウス（ICR，日本チャールス・リ バー株式会社；1 群各 5 匹）に，1日 1 回， EFE， 
Table 2. Body and Tissue Weight

\begin{tabular}{|c|c|c|c|c|c|c|c|c|c|c|c|}
\hline Sex & Group & & $\begin{array}{l}\text { Body } \\
\text { weight } \\
\text { (g) }\end{array}$ & $\begin{array}{l}\text { Thymus } \\
\text { (mg) }\end{array}$ & $\begin{array}{l}\text { Heart } \\
(\mathrm{mg})\end{array}$ & $\begin{array}{l}\text { Lung } \\
(\mathrm{mg})\end{array}$ & $\begin{array}{l}\text { Liver } \\
(\mathrm{mg})\end{array}$ & $\begin{array}{r}\text { Kidr } \\
\text { (rigl } \\
(\mathrm{m}\end{array}$ & $\begin{array}{l}\text { Kidney } \\
\text { (left) } \\
(\mathrm{mg})\end{array}$ & $\begin{array}{l}\text { Spleen } \\
(\mathrm{mg})\end{array}$ & $\begin{array}{c}\text { Stomach } \\
(\mathrm{mg})\end{array}$ \\
\hline \multirow[t]{6}{*}{ Male } & Water & $\mathrm{AVG}$ & 32.3 & 63.7 & 158.2 & 177.5 & 1939.0 & 262 & 244.4 & 97.8 & 256.1 \\
\hline & & S.D. & 1.5 & 14.6 & 13.9 & 34.0 & 186.6 & 37 & 35.0 & 16.9 & 28.3 \\
\hline & $\mathrm{EFE}$ & AVG & 30.9 & 64.9 & 152.4 & 171.2 & 1777.8 & 237 & 239.3 & 90.5 & 231.0 \\
\hline & & S.D. & 2.9 & 22.2 & 14.7 & 17.7 & 169.4 & 27 & 24.5 & 13.6 & 28.1 \\
\hline & EHE & $\mathrm{AVG}$ & 30.8 & 43.6 & 151.7 & 195.8 & 1674.2 & 243 & 238.3 & 90.3 & 252.3 \\
\hline & & S.D. & 1.2 & 6.3 & 17.8 & 43.2 & 196.9 & 22 & 21.8 & 17.7 & 22.7 \\
\hline \multirow[t]{6}{*}{ Female } & Water & $\mathrm{AVG}$ & 26.3 & 67.0 & 140.5 & 154.3 & 1350.3 & 167 & 157.2 & 88.1 & 205.7 \\
\hline & & S.D. & 2.3 & 46.4 & 14.9 & 10.2 & 162.3 & 12 & 14.0 & 13.0 & 18.2 \\
\hline & EFE & AVG & 26.1 & 55.6 & 135.9 & 158.8 & 1208.8 & 159 & 154.4 & 93.1 & 215.9 \\
\hline & & S.D. & 1.5 & 7.7 & 9.4 & 10.8 & 121.4 & 11 & 10.9 & 8.1 & 15.4 \\
\hline & EHE & AVG & 26.5 & 54.2 & 142.5 & 161.6 & 1223.6 & 171 & 172.1 & 113.9 & 216.8 \\
\hline & & S.D. & 2.8 & 13.2 & 24.1 & 13.9 & 215.5 & 29 & 35.1 & 42.2 & 26.7 \\
\hline Sex & Group & & $\begin{array}{c}\text { Small } \\
\text { intestine } \\
(\mathrm{mg})\end{array}$ & $\underset{(\mathrm{mg})}{\text { Cecum }}$ & $\begin{array}{l}\text { Colon } \\
(\mathrm{mg})\end{array}$ & $\begin{array}{l}\text { Testis } \\
(\mathrm{mg})\end{array}$ & $\begin{array}{c}\text { Vesicula } \\
\text { gland } \\
(\mathrm{mg})\end{array}$ & $\begin{array}{c}\text { Vas } \\
\text { deferens } \\
(\mathrm{mg})\end{array}$ & $\begin{array}{l}\text { Epididymis } \\
\quad(\mathrm{mg})\end{array}$ & $\begin{array}{l}\text { Ovary } \\
(\mathrm{mg})\end{array}$ & $\begin{array}{l}\text { Uterus } \\
(\mathrm{mg})\end{array}$ \\
\hline \multirow[t]{6}{*}{ Male } & Water & $\mathrm{AVG}$ & 1915.1 & 153.2 & 382.3 & 199.4 & 170.5 & 30.8 & 78.3 & - & - \\
\hline & & S.D. & 279.7 & 14.9 & 14.6 & 20.9 & 75.5 & 7.0 & 12.3 & - & - \\
\hline & EFE & $\mathrm{AVG}$ & 1741.5 & 133.5 & $310.4^{* *}$ & 199.7 & 149.3 & 26.1 & 77.0 & - & - \\
\hline & & S.D. & 318.3 & 16.2 & 35.6 & 24.3 & 37.5 & 2.3 & 6.3 & - & - \\
\hline & EHE & $\mathrm{AVG}$ & 1912.2 & 161.7 & $326.9^{*}$ & 198.6 & 126.0 & 25.7 & 74.4 & - & - \\
\hline & & S.D. & 235.0 & 33.1 & 22.5 & 13.0 & 36.8 & 3.9 & 5.8 & - & - \\
\hline \multirow[t]{6}{*}{ Female } & Water & $\mathrm{AVG}$ & 1397.0 & 121.2 & 338.6 & - & - & - & - & 13.1 & 125.9 \\
\hline & & S.D. & 144.3 & 14.3 & 91.3 & - & - & - & - & 1.0 & 43.7 \\
\hline & $\mathrm{EFE}$ & $\mathrm{AVG}$ & 1202.8 & 109.8 & 282.1 & - & - & - & - & 12.4 & 167.1 \\
\hline & & S.D. & 92.2 & 13.2 & 45.3 & - & - & - & - & 2.4 & 66.9 \\
\hline & EHE & $\mathrm{AVG}$ & 1324.4 & 140.8 & 274.1 & - & - & - & - & 13.8 & 145.4 \\
\hline & & S.D. & 217.9 & 25.5 & 22.1 & - & - & - & - & 6.2 & 53.0 \\
\hline
\end{tabular}

${ }^{*} p<0.05$ and ${ }^{* *} p<0.01 v s$. mice administered water, by Tukey's test. Reprinted from J. Nat. Med., 70 (3), 571-583.

EHE，あるいは水を 2 週間繰り返し経口投与し た. 各エキスの投与量は, 麻黄配合漢方薬の中で最 も高用量で用いられる麻黄の量（6g/日）の 50 倍 量から得られるエキス量より換算した。 EFE は 632 $\mathrm{mg} / \mathrm{kg}, \mathrm{EHE}$ は $755 \mathrm{mg} / \mathrm{kg}$ を投与した。 反復投与 の 2 週間後, 体重及び外観を記録後, イソフルラン 麻酔下で解剖し，腹部大動脈より血液を回収して, 生化学的検査及び血算を行った。投与期間中に死亡 や衰弱した個体はおらず，外観の異常も観察されな かった。マウスの体重は 3 群間で有意差はなかった (Table 2)。臓器重量については, 雄マウスの大腸 重量が EFE 群及び EHE 群で水投与群よりも低下 したが, その低下の程度は小さく, 雌マウスの大腸 重量についは 3 群間で有意差がなかった．他の臟器 重量については 3 群間で有意差はなかった（Table
2). 血清の生化学的検査項目については，3 群間で 有意差がなかった（Table 3)。一方，血算について は，雄の EHE 群が水投与群に対し血小板数が有意 に増加し，白血球数が有意に低下した（Table 4).

しかし EFE 投与群の血小板数及び白血球数は，水 投与群と比較して有意差は観察されなかつた。 以上 の結果から， EFE のヒト 50 倍量の反復投与はマウ スに対する毒性は低いことが明らかになった。ま た，雄の $\mathrm{EHE}$ 投与群は，水投与群に対し血小板数 が有意に増加し, 白血球数が有意に低下したが, EFE 投与群ではこのような異常は観察されなかっ たことから，EFE は EHEより安全性が高いことが 示唆された.

\section{EFE の健康成人に対する安全性試験}

EFE は麻黄よりも安全性の高い医薬品になる可 
Table 3. Serum Biochemical Values

\begin{tabular}{|c|c|c|c|c|c|c|c|c|c|}
\hline \multirow[t]{2}{*}{ Sex } & Para & $\begin{array}{c}\mathrm{ALB} \\
(\mathrm{g} / \mathrm{dL})\end{array}$ & $\begin{array}{c}\text { AST } \\
(\mathrm{IU} / \mathrm{L})\end{array}$ & $\begin{array}{c}\mathrm{ALT} \\
(\mathrm{IU} / \mathrm{L})\end{array}$ & $\begin{array}{c}\text { ALP } \\
(\mathrm{IU} / \mathrm{L})\end{array}$ & $\begin{array}{l}\text { LDH } \\
(\mathrm{IU} / \mathrm{L})\end{array}$ & $\begin{array}{l}\text { LAP } \\
\text { (IU/L) }\end{array}$ & $\begin{array}{l}\gamma \text {-GT } \\
(\mathrm{IU} / \mathrm{L})\end{array}$ & $\begin{array}{c}\text { T-BIL } \\
(\mathrm{mg} / \mathrm{dL})\end{array}$ \\
\hline & & $\mathrm{AVG} \pm$ & $\mathrm{AVG} \pm$ & $\mathrm{AVG} \pm$ & $\mathrm{AVG} \pm$ & AVG \pm S.D. & $\mathrm{AVG}$ & $\mathrm{AVG} \pm$ & $\mathrm{AVG}$ \\
\hline \multirow[t]{3}{*}{ Male } & er & $36=$ & 9 & $34.2 \pm$ & $292.6 \pm$ & $597.2 \pm$ & 58.4 & N.D. ${ }^{\dagger}$ & $0.08=$ \\
\hline & & 7 & & & & $765.0 \pm$ & & N.D. & 0.10 \\
\hline & $\mathrm{E}$ & $2.90 \pm 0.10$ & $53.4 \pm 4.7$ & $29.0 \pm 4.3$ & $384.6 \pm 191.2$ & $727.0 \pm 251.9$ & $60.6 \pm 2.1$ & N.D. & $0.08 \pm 0.008$ \\
\hline \multirow[t]{3}{*}{ Female } & & $3.12 \pm 0.08$ & $53.4 \pm 10.7$ & $25.0 \pm 3.9$ & $332.8 \pm 38.8$ & $435.6 \pm 214.0$ & $54.2 \pm 4.7$ & N.D. & $0.08 \pm 0.015$ \\
\hline & & $3.06 \pm 0.18$ & $55.0 \pm 9.7$ & $21.6 \pm 2.6$ & $361.2 \pm 50.6$ & $645.8 \pm 224.5$ & $55.0 \pm 3.2$ & N.D. & $0.10 \pm 0.004$ \\
\hline & EHE & $3.24 \pm 0.19$ & $57.8 \pm 6.9$ & $21.6 \pm 6.1$ & $332.4 \pm 60.1$ & $644.2 \pm 91.4$ & $58.6 \pm 7.2$ & N.D. & $0.08 \pm 0.025$ \\
\hline
\end{tabular}

${ }^{\dagger}$ N.D.: Not detectable. Reprinted from J. Nat. Med., 70 (3), 571-583.

Table 4. Haematological Values

\begin{tabular}{|c|c|c|c|c|c|c|c|c|c|c|}
\hline \multirow[t]{2}{*}{ Sex } & $\Gamma$ & $\begin{array}{c}\mathrm{RBC} \\
(10000 / \mu \mathrm{L})\end{array}$ & $\begin{array}{c}\mathrm{Hb} \\
(\mathrm{g} / \mathrm{dL})\end{array}$ & $\begin{array}{l}\mathrm{Ht} \\
(\%)\end{array}$ & $\begin{array}{c}\mathrm{PLT} \\
(10000 / \mu \mathrm{L})\end{array}$ & $\begin{array}{c}\mathrm{WBC} \\
(1000 / \mu \mathrm{L})\end{array}$ & $\begin{array}{c}\text { Neutro } \\
(\mathrm{Stab})(\%)\end{array}$ & $\begin{array}{l}\text { Neutro } \\
(\mathrm{Seg})(\%)\end{array}$ & $\begin{array}{c}\text { Lympho } \\
(\%)\end{array}$ & $\begin{array}{c}\text { Mono } \\
(\%)\end{array}$ \\
\hline & & & & & & & & & & AVG \\
\hline \multirow[t]{3}{*}{ Male } & & & & & & & & & & \\
\hline & . & $964 \pm$ & 15.6 & $49.6=$ & $48.2 \pm$ & $1.27 \pm 0.63$ & $2.6=$ & 12.9 & 74 & 4.4 \\
\hline & EHE & $976 \pm 40$ & $15.2 \pm 0.8$ & $49.5 \pm 1.8$ & $65.2 \pm 10.4^{*}$ & $0.90 \pm 0.17^{*}$ & $2.4 \pm 0.9$ & $23.6 \pm 12.4$ & 70.4 & $3.6 \pm 2.2$ \\
\hline \multirow[t]{3}{*}{ Female } & & $947 \pm 48$ & $15.5 \pm 1.4$ & $49.6 \pm 3.5$ & $44.2 \pm 12.3$ & $2.49 \pm 1.4$ & $2.0 \pm 1.0$ & $13.0 \pm 11.0$ & & $5.0 \pm 1$. \\
\hline & & $980 \pm 37$ & $15.9 \pm 0.8$ & $49.1 \pm 1.8$ & $56.5 \pm 7.4$ & $1.6 \pm 0.81$ & & & $85.0 \pm$ & $3.8 \pm 1.6$ \\
\hline & EHE & $965 \pm 52$ & $15.5 \pm 0.8$ & $49.1 \pm 1.4$ & $53.1 \pm 8.1$ & $1.99 \pm 0.76$ & $2.2 \pm 0.8$ & $12.4 \pm 6.6$ & $80.6 \pm 7.4$ & $4.8 \pm 2.3$ \\
\hline
\end{tabular}

${ }^{*} p<0.05$ vs. mice administered water, by Dunnett's test. Reprinted from J. Nat. Med., 70 (3), 571-583.

能性は高いが，一方で，EFE は first-in-human の新 規の生薬由来エキスであるため, 安全性に対する慎 重な検証が必要であった。そこで，EFEのヒトに 対する安全性を検証するために，優良臨床試験基準 (good clinical practice; GCP) に準拠した二重盲検 ランダム化クロスオーバー EHE 対照比較試験 [大 学病院医療情報ネットワーク (University Hospital Medical Information Network; UMIN) 000022061] を実施した。 ${ }^{19)}$ 健康成人 12 名をランダムに 2 グ ループに割り付けた。被検薬 $\mathrm{EFE}$ と対照薬 $\mathrm{EHE}$ のいずれも 1 日量として麻黄 $6 \mathrm{~g}$ を煎じた量に相当 するエキス量を，6日間，連日服用させた４ 週間 の休薬期間を設け，後半には前半で服用しなかった 試験薬を服用させた（Fig. 4). 未梢血液検査所見， 血液生化学所見，尿検査所見，12 誘導心電図所 見, 自覚症状, 身体所見の変化を統計的に評価し た。その結果, EHE 群 (12 例), EFE 群 (12 例) それぞれの試験薬と因果関係を有する有害事象の発 生頻度は脈拍数上昇 (4 例 vs. 1 例, $p=0.32)$, 不 眠 (3 例 vs. 1 例, $p=0.59)$, ほてり (0 例 vs. 1 例, $p=1.00)$ ，排尿困難（1 例 vs. 0 例, $p=1.00)$ と, いずれも両群間に有意差を認めなかつたが，有害事 象全般の発生頻度は, EFE は EHEの 3 分の 1 で, EFE は EHE に比較して相対的に安全性が高いこと が示唆された（Table 5).

7. おわりに

麻黄はエフェドリンアルカロイドを含有するた め, 中枢神経や交感神経に対する刺激を介した副作 用を惹起したり，心筋，膀胱平滑筋や外尿道括約筋 に影響を与えたりする可能性が高い。また，エフエ ドリンアルカロイドは WADA によって禁止薬物に 指定されているため, 麻黄配合漢方薬は“うっかり ドーピング” 20)を発生させる危険性も高い。われわ れは，こうした麻黄の有害事象を軽減し，安全性の 高い生薬エキスを開発するために研究を行ってき た. 麻黄エキスからエフェドリンアルカロイドを除 去しても，いくつかの有用な麻黄の薬理作用が残る ことは, 2017 年の薬学雑誌の誌上シンポジウム ${ }^{21)}$ で詳細に述べたので, 本稿では, エフェドリンアル カロイドに由来する有害事象を中心に，われわれの 


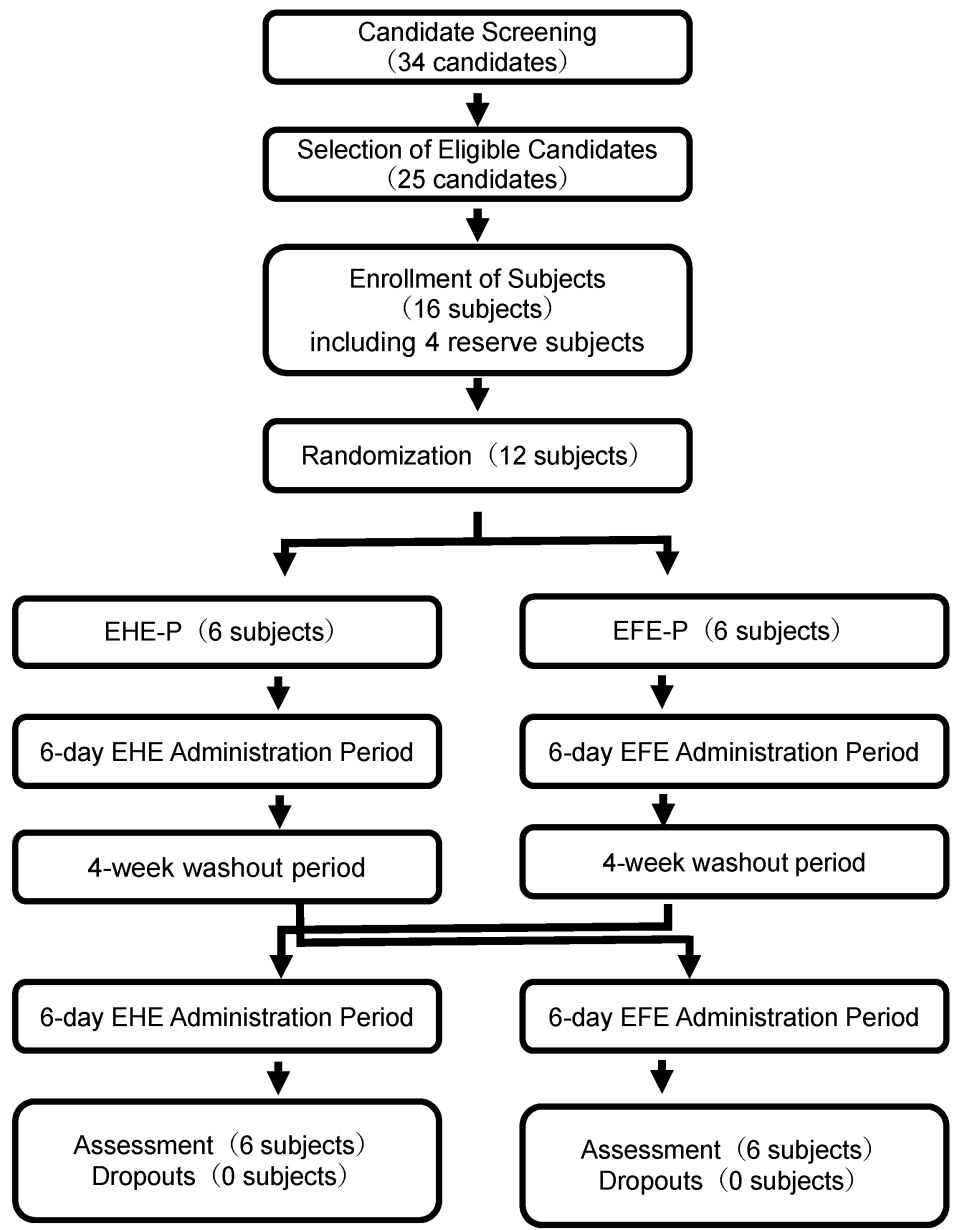

Fig. 4. Clinical Trial Flowchart Reprinted from Evid. Based Complement. Altemat. Med., 2018, Article ID 4625358.

Table 5. Comparison of Various Adverse Events during EFE and EHE Administration

\begin{tabular}{|c|c|c|c|c|}
\hline & \multicolumn{3}{|c|}{ Incidence of adverse events } & \multirow{2}{*}{$\begin{array}{l}\text { Odds ratio (confidence interval) of } \\
\text { incidence during EFE administration } \\
\text { /during EHE administration }\end{array}$} \\
\hline & $\begin{array}{l}\text { During EFE } \\
\text { administration }\end{array}$ & $\begin{array}{l}\text { During EHE } \\
\text { administration }\end{array}$ & $p$ value & \\
\hline Increased pulse rate & 1 case $/ 12$ cases & 4 cases $/ 12$ cases & 0.32 & $0.18(0.01-1.52)$ \\
\hline Insomnia & 1 case $/ 12$ cases & 3 cases $/ 12$ cases & 0.59 & $0.27(0.01-2.56)$ \\
\hline Hot flash & 1 case $/ 12$ cases & 0 case $/ 12$ cases & 1.00 & not applicable \\
\hline Dysuria & 0 case $/ 12$ cases & 1 case $/ 12$ cases & 1.00 & not applicable \\
\hline
\end{tabular}

$p$ value derived from Fisher's exact test. Reprinted from Evid. Based Complement. Altemat. Med., 2018, Article ID 4625358.

オリジナル論文の内容を総説としてまとめた。その 結果，エフェドリンアルカロイドを除去した麻黄エ キスは，麻黄エキスの有する副作用を発現せず，麻 黄エキスよりも安全性が高いことが示唆された。

今後は EFE を, 安全性の高い天然物由来エキス として，高齢者の膝関節痛やがん患者の術後補助療 法への応用，さらにはインフルエンザ治療薬や，cMet 発現がんの治療薬，また EFE 含有漢方処方製
剤等として，臨床応用していきたいと考えており， EFEの製品化のために，品質評価法の開発や，有 効性を評価するための臨床研究プロトコールの検討 を進めているところである.

倫理指針 1）動物実験は，北里大学北里生命 科学研究所動物実験委員会，及び，国立医薬品食品 衛生研究所動物実験委員会で承認され，動物実験等 に関する規定に従って実施された。2）医師主導型 
臨床研究は, 北里大学相模原治験審査委員会で承認 され，人を対象とする医学系研究に関する倫理指針 に従って実施された。

謝辞本研究の一部は, 国立研究開発法人日本 医療研究開発機構 (Japan Agency for Medical Research and Development; AMED) 委託研究開発 費 創薬基盤推進研究事業「次世代医薬品の効率的 実用化推進のための品質評価技術基盤の開発」及び All Kitasato Project Study（AKPS）共同研究助成金 により実施した。この場を借りて厚く御礼申し上げ ます。

利益相反 1）北里大学東洋医学総合研究所 （株式会社ツムラより寄附金を受領），2）小田口 浩, 日向須美子（救心製薬株式会社より共同研究費 を受領)，3）嶋田典基，楊 金緯（株式会社常磐植 物化学研究所の社員)，4）小田口 浩, 日向須美 子，中森俊輔，大嶋直浩，楊 金緯，天倉吉章，日 向昌司，小林義典，袴塚高志，合田幸広，花輪壽彦 （特許権使用料・ライセンス料の受領はないが，株 式会社常磐植物化学研究所及びゼリア新薬工業株式 会社と共同出願中).

\section{REFERENCES}

1) Ministry of Health, Labour and Welfare of Japan, “The Japanese Pharmacopoeia," 17th Edition, 2016.

2) Nagai N., Yakugaku Zasshi, 1186-1193 (1892).

3) Nishioka I., Yakugaku Zasshi, 103, 125-142 (1983).

4) Hikino H., Konno H., Takata H., Tamada M., Chem. Pharm. Bull., 28, 2900-2904 (1980).

5) Kasahara Y., Hikino H., Tsurufuji S., Watanabe M., Ohuchi K., Planta Med., 51, 325-331 (1985).

6) Harada T., The Journal of Traditional SinoJapanese Medicine, 1, 34-39 (1980).

7) Takeda S., Miura K., Igarashi T., Kobayashi M., Watanabe R., Furukawa M., Ayabe R., Seki N., Prog. Med., 31, 1579-1586 (2011).

8) Yamamura H., Fukuda S., Tokuoka Y., J. New Rem. \& Clin., 45, 115-126 (1997).
9) U.S. Department of Health and Human Services, Food and Drug Administration, Fed. Regist., 69, 6787-6854 (2004).

10) Haller C. A., Benowitz N. L., N. Engl. J. Med., 343, 1833-1838 (2000).

11) Nakae H., Igarashi T., Jpn. J. Occup. Med. Traumatol., 62, 202-205 (2014).

12) Hyuga S., Hyuga M., Yoshimura M., Amakura Y., Goda Y., Hanawa T., Planta Med., 79, 1525-1530 (2013).

13) Hyuga S., Hyuga M., Oshima N., Maruyama T., Kamakura H., Yamashita T., Yoshimura M., Amakura Y., Hakamatsuka T., Odaguchi H., Goda Y., Hanawa T., J. Nat. Med., 70, 571-583 (2016).

14) Oshima N., Yamashita T., Hyuga S., Hyuga M., Kamakura H., Yoshimura M., Maruyama T., Hakamatsuka T., Amakura Y., Hanawa T., Goda Y., J. Nat. Med., 70, 554-562 (2016).

15) Nakamori S., Takahashi J., Hyuga S., Yang J., Takemoto H., Maruyama T., Oshima N., Uchiyama N., Amakura Y., Hyuga M., Hakamatsuka T., Goda Y., Odaguchi H., Hanawa T., Kobayashia Y., Biol. Pharm. Bull., 42, 1538-1544 (2019).

16) Ohara S., J. Jpn. Wood Res. Soc., 55, 59-68 (2009).

17) Steynberg J. P., Bezuidenhoudt B. C. B., Burger J. F. W., Young D. A., Ferreira D., J. Chem. Soc. Perkin Trans. 1, 203-208 (1990).

18) Takemoto H., Takahashi J., Hyuga S., Odaguchi H., Uchiyama N., Maruyama T., Yamashita Y., Hyuga M., Oshima N., Amakura Y., Hakamatsuka T., Goda Y., Hanawa T., Kobayashi Y., Biol. Pharm. Bull., 41, 247-253 (2018).

19) Odaguchi H., Sekine M., Hyuga S., Hanawa T., Hoshi K., Sasaki Y., Aso M., Yang J., Hyuga M., Kobayashi Y., Hakamatsuka T., Goda Y., Kumagai Y., Evid. Based Complement. Alternat. Med., 4625358 (2018).

20) Japan Pharmaceutical Association: 〈https:// www.nichiyaku.or.jp / activities / anti-doping / about.html $\rangle$, cited 8 May, 2019.

21) Hyuga S., Yakugaku Zasshi, 137, 179-186 (2017). 